\title{
Matar's Representation of Cultural and Political Manifestations of Libya
}

By:

Nada Abdulsalam Abdulrahman

\author{
Prof: Abdulgawad Ali Elnady \\ Professor of literature- Faculty of Arts - Tanta University
}

\author{
Assoc.Prof: Moetaz Elsorogy \\ Associate professor of literature Associate professor of literature \\ Faculty of Arts - Tanta University
}

\begin{abstract}
:
Writings by Libyans in Western countries remained dormant until recently. Autobiography has been a most favorite genre for the Libyan writers, through which prominent figures on the Libyan scene started communicating their experiences and sufferings under Qaddafi's regime. They found in literature the means to resist "silence and misrepresentation" (Swindells 7). Ibrahim al-Koni, Ahmed Fagih, and Hisham Matar are some of the Libyan novelists who are familiar with history, landscape and cultural practices of the Libyans. Hisham Matar paints a clear picture of complex and intertwined political events that may have led to the fall of Muammar Qaddafi himself.In almost all of his writings, Matar is profoundly concerned with the Libyan political and cultural affairs. He might have chosen exotic settings and peculiar forms for his novels, but deep inside, and at the core of all he writes, there is that feeling that his target is the Libyan locale and the Libyan citizen, politically and culturally. Underneath the tragedy of the loss of his father, the author devoted a large part of his novels to the atrocities of the Qaddafi regime in a clear token of protest against it yet in the form of cultural rather than violent resistance.
\end{abstract}

Hisham Matar resorts to the cultural and political manifestations of Libya to shape the consciousness of his readers, making them much more aware of the dilemma of Libyan people in the postmodern age. He succeeded to attract the attention of Western society to his father's case, and also he 
shows the potential of utilizing the English language in expressing the nature and stories of the Libyan community.

\section{Keywords: Cultural and Political , Libya}

\section{Introduction}

The Libyan poet and novelist Hisham Matar was born in 1970 in New York City, the second of two sons, he spent his childhood in Cairo, the city where his family chose to settle into exile in 1978. he was educated at Goldsmith's College in London and was nominated for the Man Booker Prize. He currently ,lives in London and New York, where he is a Fellow of the Royal Society of Literature, and Associate Professor at Barnard College, Columbia University.

His father, Jaballah Matar was posted as a United Nations Official. When Hisham was at the age of three, the family returned to Tripoli, the capital of Libya, where Qaddafi had declared his notorious cultural revolution which includes the formation of people's committees in schools, hospitals, universities, workplaces, and administrative districts. Political parties were already banned in 1972 and all elections were non- partisan under the law until the advent of the Arab Spring in 2011. Joining a political party or participating in any political events or manifestations was outlawed and carried the death sentence without trial. Qaddafi would not tolerate any political activities outside his ideology.

Against this background, several students, school teachers, university professors, and government employees were hunted down, persecuted, jailed, or simply murdered in cold blood in broad daylight. The political turmoil resulted in a mass immigration of several intellectuals, educated cadres and officials all fleeing the barbaric repression led by the regime's cronies. Ever since the disappearance of his father, Hisham and his family have lived in London most of his adult life. His father was taken to Abu Salim prison in Tripoli, says Hisham, "which was known as the last stop, the place the regime sent those it wanted to forget. I never saw him again" (Return18).

The researcher selected three novels which were written by Hisham Matar .These novels are in The Country of Men (2006), Anatomy of a Disappearance 
(2011) The Return (2016). Whether in the form of novel, as In the Country of Men and Anatomy of a Disappearance, or in the form of memoir, as in The Return, Matar explores a wide range of issues and situations with extreme sensitivity and attention to detail. In each of these three works, the story of a family is closely intertwined with the political events happening in his homeland Libya, where unprecedented violence and repression are frequent, forcing exile upon the most prominent opponents of the dictatorial regime and leaving indelible marks of suffering on individual and society. This research will depict cultural and political manifestations of Libya before and after Qaddafi's era, in addition to Libyan literature, historical events, folktales as shown in Hisham Matar's novels: In the County of Men, Anatomy of a Disappearance, and The Return.

Matar's works are devoted to memory and loss; especially the loss of his father and his homeland, Libya. For Matar, Libya represented the first secure corner in the world and when he left "as if part of me had stopped developing the moment we left Libya" (Return 17). In an article published in The Guardian, Hisham Matar writes about an episode which occurred during his childhood, a few years before leaving Libya. One afternoon, while playing under the sun, one of his friends asked him to sketch anything on the sand with a stick he has just found. Hisham decides to draw the map of Libya. In his memoir The Return, Matar pays attention to the smallest details such as geographical location and census of Libya.

("words were not dangerous" n.page).

Libya is a North African country with a relatively small population considering its vast geographical size. The first census carried out in Libya was in 1931. The population then was 700,000 . Therefore, judging by how the population climbed after 1931, it would be reasonable to assume that back in the 1880s the population of the territory we now know as Libya was somewhere between 250,000 and 500,000 (Return 102). Factually, the latest population census, cites no more than six million inhabitants nationally, mostly scattered along the coastal stretch between southern Tunisia and western Egypt .Urban areas also exist in the south, with small populations that inhabit mostly Saharan oases like Kufra, Jaloe, Gadames, Sebha etc. These have always been marginalized due to their remote locations and the relatively poor road and air infrastructure. Their importance only stems from the fact that the bulk of Libyan economy relies on the existence of massive oil, water, reserves that feed the economic activities of coastal urban areas. 
Ever since its independence in the early 1950s, Libya as we know it today, independent sovereign state and United Nations member, is a developing country, which has faced a number of political, economic and social challenges that culminated in the bloody uprising of 2011. The uprising beginning in Benghazi, "Benghazi [that] city had always been unenthusiastic about the Qaddafi regime, and it paid the price" (Return 119). The uprising began on the 15th of February 2011, with protests over the arrest of Fathi Terbil, a legal advocate for families of victims of the 1996 Abu Salim prison massacre.

Fathi Terbil, a lawyer who had represented the relatives of over one thousand political prisoners killed in Abu Salim prison, was arrested. It was in response to this that on the night of the 15th of February 2011, two days before the planned beginning of the Libyan revolution (97). The opposition controlled most of Benghazi, the country's second-largest city. The government dispatched elite troops and mercenaries in an attempt to recapture it, but they were repelled. The activities of these mercenaries and elite troops are no different from the activities of the Revolutionary Committee Men in Hisham Matar's novel, In the Country of Men, he mentioned them as "Revolutionary Committee Men, or Mokhabarat, people we called Antennae" (14). These men in Matar's novel act with impunity ,and without regard for due process. This issue of discontentment is one of the key issues that plays a significant part in the events leading up to the Libyan Revolution in 2011 and the eventual overthrow of the Qaddafi regime.

The concerted efforts by the dictatorial regime to create a new kind of Libyan citizen targeted younger generations in particular through educational and mass- media programs of indoctrination. University students and professors, in particular, were its initial victims as new revolutionary "political culture" with all its orientation, beliefs, attitudes, values, and objectives forced upon a newly emerging "intellectual" force capable of shaking the very basis of the regime's ideology. Qaddafi tried to impose his slogans and ideas on the younger generations. All the slogans that were hammered into our ears, which, as children, we were forced to repeat at school, had formed our education as Matar writes:

A house belongs to whoever lives in it, which legalized the theft of private property, had indoctrinated in many of us a disregard of the law. "The masses rule. Representative politics is not democracy. True democracy is by mass rule and the masses must be armed." These 
were the slogans that bombarded us from 1969 till 2011 .(Return 162)

Even traditional political participation in the events shaping the political and economic future of the nation was re-defined. The very act of participating in the formulation, passage, or implementation of policies took new dimensions. The "Jamahirian" citizen is subjected to all forms of" Jamahirian" values and attitudes that are in concordance with the regime's doctrine. The reality of the regime's political indoctrination fell on deaf ears as the tools by which this ideology was inculcated gradually turned into lethal weapons in the hands of an ever-growing intellectual class of dissidents. Since education, not the family, is much easier to control by the regime and is a much more direct tool of political indoctrination,

Qaddafi's regime used and abused the educational system to fulfill its objectives. It is through educational platforms that the regime proved in 2011, the regime proved its previous unsuccessful endeavors to instill a form of culture using textbooks and politically indoctrinated regime instructors whose duty was to contribute to the birth of "political awareness" as prescribed by the regime's intelligentsia.

These endeavors were backed by another and more effective tool, that of mass media which was totally controlled by the dictational regime from 1969 to the advent of cable and satellite broadcast.There was also and the internet the regime was able not only to control, but to direct all forms of information content broadcast via television, radio, newspapers, magazine, etc. Little or no written material in the form of newspapers, magazines or books was allowed into the country. A very strict system of censorship was set up to ensure total isolation of the public from "imported" political, cultural or intellectual content said to be iniquitous and counterrevolutionary." For four decades under Qaddafi, journalists were censored, imprisoned and sometimes killed" (Return 82).

Ever since April 1973 when a new popular revolutionary culture was declared, Qaddafi declared that political parties were the main obstacle preventing the revolution from making progress and said that he would not tolerate any political activities outside his ideology and that membership in any political party was a crime punishable by death. Following this a substantial number of students, professors and government officials were hunted down, jailed or executed, some publicly. Some of those arrested were shown on national television, confessing to anti-regime activities. Libya, Qaddafi declared, would be governed by "Revolutionary committees" 
who would take over offices in the universities and government sector. The Revolutionary Committee, a body acting as a watchdog for the regime to target dissidents and Qaddafi opponents, intimidates and terrorizes the masses and arrests and summarily executed top army cadres who favored a return to traditional forms of government (Asser "Qaddafi's Story" n.pag).

The 1990s witnessed more horrific events. The most significant atrocity of the Qaddafi era was the 1996 mass killing at Abu Salim prison, which was known as "The Last Stop", the place where the regime sent those it wanted to forget (Return 14). Abu Salim housed political prisoners, usually arrested without warrants and held incommunicado and in deplorable conditions for years. Torture was endemic. Detainees were allowed limited access to their families, denied medical treatment and deprived of any recreational activities or outdoor space for long periods of time. Abu Salim Prison, in Tripoli, is where Jaballah Matar was imprisoned after his abduction. Nikki Barrowclough reports in The Sunday Morning Herald that Jaballah managed to smuggle out two letters to his family in 1992 and 1995. Barrowclough adds that although Libyan prisons were opened during the revolution against Qaddafi's decades-long rule in 2011, Jaballah did not resurface as a survivor. He is believed to have perished in light of the absence of any evidence that proves he is alive.

Jaballah warns in his first letter, which we received in 1993, that no one should learn of the correspondence he has sent: "or else," he writes, "I will fall into a bottomless abyss". He would prefer to die under torture than give the names of those who have delivered this letter (Return 120). Jaballah was tortured so badly that he could not stand up at night to talk to other prisoners as usual. "It went on for three days. Then they moved him" (120).

On 28 June 1996, prisoners rioted, calling for better conditions or for their cases to be processed. After negotiations with senior government officials-allegedly including intelligence chief and Qaddafi's brother in-law Abdullah Al-Senussi, soldiers arrived, herding the prisoners into courtyards. Jaballah Matar was amongst those who were brought into the courtyard that day, most likely, "Father was killed in the massacre at Abu Salim. Several of the prisoners had told me that although they did not see him, they had heard from others that" (164).

They then threw grenades at the prisoners, shooting those attempting to flee. Within two days, over 1,200 prisoners were dead. Family members were not informed of the deaths until 2008, when Benghazi court ruled that 
authorities must reveal the whereabouts of thirty-three individuals believed to have died in Abu Salim. (10) Some families chose to receive compensation for the deaths, but others refused and subsequently regularly protested in Benghazi. The protests sparking the revolution were led by Abu Salim victims' families after two prominent members of the Organizing Committee of Families of Victims of Abu Salim were arrested (Wierda155). Through Matar's memoir, Abu Salim prison joins an infamous list of places of state violence besides concentration camps ; prisons such as Abu Ghraib, Tadmor, Guantanamo, where inhuman cruelty to human bodies and spirits aimed to break and destroy political forces of opposition. It covers the history of colonial Libya (Brant 6).

The fate of Libya for decades was shaped by a deranged megalomaniac man, but new generations enlightened by the advent of modern technology satellite, tv, internet etc., no longer settled for the obsolete dictatorial regime Qaddafi controlled. Years of brutal repression and economic stagnation had taken their toll on an ever -restless young generation eager to benefit from their country's extremely vast oil wealth which they thought was squandered by a reckless megalomaniac leader on foreign terrorist groups and anti-western organizations worldwide.

Over forty years of harsh dictatorial rule, did little to convince Libyans to embrace and practice the principles of Qaddafi's third universal theory "The Green Book" and he, in turn, was bitterly disappointed by their lack of interest and commitment to his outlandish revolutionary ideals. The fundamental social, economic and political changes he had dreamed of were met with apathy and reluctance on the greater part of the Libyan population whose memory of the brutal bloodshed of the seventies and early eighties had left indelible marks on the social fabric of the country. It is worth mentioning that the close-knit, mainly tribal, social background of Libyan families made it hard to forget past injuries let alone to forgive them.

From east to west, north to south, Libyans were united in one very complex yet tightly bonded extended family. Both pro and anti-regime members coexisted within the same family as in 2011, the divide became narrower and almost disappeared enabling the new uprising not only to claim success over the authoritarian regime but, more importantly, to prompt pro-regime agents to side with the people's massive nationwide rebellion.

Although most of Matar's works tend to be political, Matar devoted large parts to come across to the Libyan culture including social habits, arts, literature, and architecture and how Libyan literature with a plethora of 
talented and dedicated writers has an acclaimed place in world literature.

In his memoir, Matar throws light on the cultural heritage of Libya's second largest city, and emphasizes its richness through depicting the variety of its architecture which reflects the diversity of its cultural tributaries, and which bears witness to the successive great civilizations invading Libya over history such as the Greeks, the Romans, and the Ottomans. When describing his visit to Benghazi, Matar writes:

Scattered around it are the remains of several buried cities: a Greek wall that dates back some 2300 years, ruins from a Roman settlement, Byzantine church, and I am sure, if excavations were conducted clues to Phoenician life would be found too. From here the living city begins, the houses and markets of the medieval Arabic city together with what the Ottomans added. (Return 120).

According to Professor Hatem Ben Jemia in his published paper, Matar establishes a parallel between the burial of ancient cities in Benghazi over time and the repression and marginalization of Libyan history by its invaders. In as much as Western historians sought to underrate the history of Libyan people and to their cultural memory, he attempts to foreground the originality of Libyan pre-colonial history and to celebrate its richness" (36).

Family stories and folktales play a pivotal role in the historical texts. Family stories, which convey mostly unknown experiences of suffering and resistance during colonial and postcolonial Libya, Matar depicts, in one of these poignant stories, the horrible experience of concentration camps and the pertaining policy of genocide traditionally practiced by the fascist regimes against innocent unarmed people including native people of the countries they invaded such as the natives of Italian Libya, Matar reports that: the tribal population was marched on foot to several concentration camps across the country. Every family lost members in these camps. Several of $\{\mathrm{my}\}$ forbearers died there. Stories of torture, humiliation and famine have filtered down through the generations (Return 153).

It is not clear how many perished in the camps. Official Italian census records show that the population of Cyrenaica plummeted from 225,000 to 142,000 . The orphans, numbering in the thousands, were sent to Fascist camps to be "reeducated." Brand-new planes 
machine-gunned herds of livestock. An Italian general boasted that between 1930 and 1931 the army reduced the number of sheep and goats from 270,000 to 67,000 . As a consequence, many people starved to death. (108)

As mentioned in some oral poetry of Abuhweish (Libyan poet) who was a scholar and a teacher and later served as a jurist in Algeria and Chad and who returned home to Libya in 1911 to join the resistance; when the Italians attacked his village, they burnt down the houses and poured concrete in the well. They marched him and his family, along with the rest of the villagers, 400 kilometres to the infamous El-Agheila concentration camp. Being forbidden pens and paper, he composed a thirty-stanza-long poem that he committed to memory. It was memorized by others and that way spread across the country (108). It so fortified the spirit of resistance that when the Italians uncovered the identity of its author, they whipped him. Matar depicts the horrors of the colonial epoch and transmits the tormenting feeling of loss and sorrow. He offers, through an eloquently written poem, an important historical material which unveils an unauthorized version of colonial Libya's biography. Matar translates to English one of his poems. He writes:

I have no illness but El- Agheila camp

The imprisonment of the tribe

And being cut off from the open

country I have no illness but this

endless despair,

the scarcity of things and the loss of my red

mare its forelegs black to the hoofs

When disaster struck

She galloped, stretching her long

neck With incomparable beauty

I have no illness but the loss of noble

folk and the foul ones who now

with calamitous, shameless faces, govern

us. How many child have they taken and

whipped?

The poor young flowers return

confused? made old without having

lived. (Return 156)

The touching poems he composed had, according to Matar, a profound 
impact on Libyan people since they were "committed to memory" and "memorized by others" and that [t]he blurring of history, story, and genealogy is another form of resistance to the official stories embedded in each of these narratives.

The moving words of Abuhweish become the bridge which allows the people of Libya to reconnect emotionally with the history of their forefathers, but they become also an important historical material which helps Libyan historians to partly fill the obvious historical voids endemic in the narrative of official documents. These literary texts enable, furthermore, the Western Anglophone audience to know what actually happened during the Italian occupation of his native country (Ben Jemia 35).

Matar reveals to the reader, through his heartrending depiction, the distress of thousands of families who bore the brunt of a cruel tyrannical fascist rule which transformed their plain and serene lives into a real nightmare. Through his poems which straddle the borders between literature and history, between national and family stories, and between the personal and the collective experience of resistance and trauma, Abuhweish documents an important yet little-known phase of colonial Libya's history.

It is very important for historians because it illustrates untold stories about the terrifying experience in an extract whereby, he offers "a troubling account" of collective sufferings he witnessed when passing through one of the concentration camps in the Libyan Desert (Return 54). Quoting from Holmboe's book, Matar writes:

The camp was immense. It contained at least fifteen hundred tents and had a population of six to eight thousand people ,as we drove up among the

tents children came running towards us. They were in rags and hungry, half starved ... Many of them seemed ill and wretched, limping along with crooked backs, or with arms and legs that were terribly deformed. (54).

One of the most important historical symbols mentioned by Matar was Omar al- Mukhtar, the man we grew up referring to affectionately as "Sidi Omar", Omar al- Mukhtar led Libya's tribesmen on horseback in what became a very effective campaign. But when Benito Mussolini seized power, the destruction and slaughter took on a massive scale. Airpower was employed to gas and bomb villages. The policy was that of depopulation. History remembers Mussolini as the buffoonish Fascist, the ineffective" silly 
man of Italy who led a lame military campaign in the Second World War, but in Libya he oversaw a campaign of genocide" (Return 153).

Omar al-Mukhtar who was by then seventy-three years old, was wounded in a rapid retreat and fell off his horse. Five days later, and after a show trial, "the great man was hanged on the outskirts of Benghazi. Just as the Qaddafi regime did half a century later, when traffic was diverted so that commuters were obliged to witness the bodies of the students dangling in the garden of the Benghazi Cathedral" (110). The Italian colonial administration made sure that "Sidi Omar's execution was attended by as large a number of Libyans as possible. It broke the spirit of the Country" (111). Over the next two years the resistance, a formidable force that had inspired several independence movements around the world, disintegrated. It was then that many of its members fled to Alexandria.

Stories represent a way of preserving and passing on some precious testimonies that the course of history would inevitably engulf and forget. In fact, as Hisham writes of his relatives' stories about their imprisonment, he had the impression that by, sharing the story of the imprisonment it is a way to affirm the victory of light over the darkness of the prison cell.

Not only human actions surrender to the course of history nor building but literature and art play a major role in Matar's life and represent spaces where he can find consolation and the projection of his own nightmares. For Hisham the sound of poetry has the power to evoke Jaballah's voice when reciting poetry and open up spaces as vast as the sea and as luminous as hope. Matar mentioned his father's love for Libyan poetry "Father sought refuge in the elegiac Bedouin poetry of the alam". The word alam means 'knowledge' or 'banner" or "flag". It's a poetic form that privileges the past over the present. It is popular across Cyrenaica, but no more so than in Ajdabiya (59).

In the field of literature and culture manifestations Matar mentioned "The Scholar" "A journal published by the students of the Teachers' College of Cyrenaica in 1957", The journal's motto was: "Education gains the nation its dignity, sovereignty and pride. Where knowledge spreads, prosperity, happiness and security prevail. Education is as necessary as water and oxygen." This was the sentiment of the time. Libya was trying to drag itself into modernity. The policy of the Italian colonial government did not promote education for the "indigenous" population. Libya's oldest university 
was not established until 1955 only two years before this issue of The Scholar was published by royal decree by King Idris to commemorate the fourth anniversary of independence. Oil was yet to be discovered. Probably because of its association with literacy, the Faculty of Literature was the first academy to be established. Even such a modest start had to rely on foreign donations. Egypt contributed four lecturers, covering their salaries for four years, and the United States paid the wages of the Iraqi scholar Majid Khadduri, who eventually became dean. A year later, in 1956, the Faculty of Science was established; Economics in 1957; Law in 1962; Agriculture in 1966; and Medicine in 1970 (94).

Libyan literature had a kind of golden era in the early seventies just after Muammar Qaddafi came to power. For a brief time, Qaddafi was seen as a liberator, and he inspired hope in people in all arenas - from business to art. But Matar says that quite suddenly shattered, in one terrible moment. "In one year [Qaddafi] imprisoned a huge number of writers", Matar tells Renee Montagne on Morning Edition. "The revolutionary committee set up a sort of big literary festival, if you like, and then they just captured all the writers, they tortured them, and they put them in prison and that generation of writers spent a minimum 10 years in prison." (Matar, "Power of Libyan Fiction")

Poems can also be compared to a sort of glue that helps individuals to keep the pieces together when life challenges them. While in prison, over the years, Uncle Mahmoud managed to write poems and letters on a pillowcase and to bring it outside Abu Salim by sewing it to the waistband of his underpants'. When he shows Hisham the pillowcase, which is 'possibly the only surviving literature from all the countless volumes that have been authored inside Abu Salim prison', Hisham compares it to 'a diagram of the human anatomy:one letter in the shape of a kidney, another filling up a lung, a poem doing its best to occupy the gap between' (Return 274)

Then, in Anatomy of a Disappearance, the father figure is shown as being particularly attached to a book, one 'he had hardly parted since [his wife] died': Badr Shakir al Sayyab's Rain Song. And Nuri, who usually tried to follow the track of his father's thoughts by reading the same newspaper articles his father read or passages from the books he had with him, could not understand what 'a man so single-mindedly committed to never-uttered plans, a man who consulted only history and news and who seemed to apply 
his attention with efficient precision to his designs, saw in al-Sayyab's poetry' (Anatomy 26-7).

He could not think that his father, a man so focused on his job and political involvement, could be endowed with such great sensitivity and depth; he was convinced that that was exclusively his 'Mother's territory. [...] But perhaps [he] had misread him. Perhaps he did find a small landing place on the verses of al-Sayyab. Perhaps he did understand her' .Love for literature runs through Matar's work, where it is mainly represented as both a source of pleasure and delight and a source of hope and consolation during the darkest times. 


\section{Conclusion}

Hisham Matar's works have earned praise across the Arab literary world including his own country of origin. However, the fact remains that Libya is today in dire need of institutions and frameworks capable of disseminating the rich cultural heritage which the old regime of Qaddafi had smothered for over forty years, preferring to impose a model of brutal dogmatism instead. Matar's masterpieces are circulated among the intellectual elite of the country. However, very few book lovers would afford the luxury of purchasing any of his books from local bookstores as these would hardly risk investing in imported works of literature mainly because of high cost and scarce clientele. In one of his interviews Matar stated that some described his novels as "The Sheikhs novels" because of its high prices. A number of several international and national online newspapers have run translated reviews of his works, like AfricaGate, Marefa, Aljazeera, Net Culture and Art, Libya Almostaqbal, and others. The writer contributed articles and interviews to the press and media worldwide.

Matar provides an insight into how individuals can cope with tragedies, loss and injustice his works paint pictures of landscapes that are highly evocative of states of mind. Besides being works of extremely high literary value.Matar shed light on the history of Libya, and how for 42 years, up until his death in October 2011, Qaddafi ruled over Libya and its people with impunity. Forced uncompensated nationalisation and confiscation of private property was prevalent in the 1970s, as were assassinations and executions of political activists in Libya and abroad in the 1980s. The massacre of over 1,000 prisoners at Abu Salim in the 1990s passed underreported and unpunished, as did the false imprisonments of hundreds of Libyans, many of whom were held without trial, tortured and spent decades confined in unfathomable conditions. Not only the historical manifestations of Libya, but he tries to say, there is another Libya. It has art, music, cafes, surprisingly thriving. It has human beings, who care about family, who remember and recite poetry, who believe in peaceful and prosperous civil society.

Matar's ultimate goal is to enhance historical writings in new Libya, but also to conscientize the young uninformed and even the informed but frightened and lethargic to what happened in modern Libya including what 
happened during the earlier epoch of colonization. Moreover, through writing in English and through having recourse to clarity and directness in elaborating his attitudes and perceptions, Matar is targeting Anglophone and international audiences whose knowledge of the history of political oppression in Libya is limited. 


\section{Works Cited}

Asser, Martin. "The Muammar Gaddafi Story".BBC,20 2012, https://www.bbc.com/news/world-africa-12688033. Accessed 4 Aug 2019.

Bin Jemia,Hatem. "Family stories and Counter-history." Tayr Quarterly Journal.University of Manouba,Volume 6, March 2019.

Brant, Clare. "Hisham Matar. The Return: Fathers, Sons and the Land in Between". The European Journal of Life Writing, vol 7, 2018, pp. 4:8., Accessed 8.May.2019.

Matar, Hisham. The Return: Fathers, Sons, and the Land in Between. New York, NY: Penguin Books.2017.

.--- In the Country of Men. New York, NY: The Dial Press, 2006. Print.

--- Anatomy of a Disappearance. New York, NY: The Dial Press, 2011. Print.

--- "The Power of Libyan Fiction". Morning Edition, April 28,2011. https://www.npr.org/2011/04/28/135782783/hisham-matar-on-the-power-oflibyan-fiction. Accessed $\underline{6}$ Aug 2019

Matar, Hisham. I don't remember a time when words were not dangerous. The Guardian.June,2016. Retrieved September 24, 2019 from https://www.theguardian.com/books/2016/jun/25/hisham-matar-i-dontremember-a-timewhen-words-were-not-dangerous.

Swindells, Julia. Introduction. The Uses of Autobiography. Julia Swindells ed. London: Taylor\& Francis, 1995.

Wierda,Marieke." Confronting Qadhafi's Legacy: Transitional Justice in Libya." The Libyan Revolution and its Aftermath. Eds.Peter cole,Brian Mcquin. NewYork.Oxford University press.2016. 
الممارسات السياسية والثقافية في أعمال هشام مطر

إعداد

ندي عبد السلام عبد الرحمن

أ.د عبد الجواد النادي

أستاذ الأدب الإنجليزي، كلية الأداب ــامعة طنطا

أ.م معتز إبراهيم السروجي

أستاذ مساعد ورئيس قسم اللغة الإنجليزية ،كلية الأداب -جامعة طنطا

المستخلص:

ظلت كتابات الليبيين في الدول الغربيةو العربية مجهولةً حتى وقت قريب. تعد السيرة الذاتية من أكثر الأنواع المفضلة للكتاب الليبيين ، والتي من خلالها بدأت شخصيات بارزة على الساحة الليبية في نقل تجاربهم ومعاناتهم في ظل نظام القذافي وجدوا في الأدب وسيلة لمقاومة "الصمت و التحريف" (سويندلز V). إبر اهيم الكوني و أحمد فقيه وهشام مطر من الروائيين الليبيين المطلعين على التاريخ والمناظر الطبيعية والمدارسات الثقافية لليبيين.

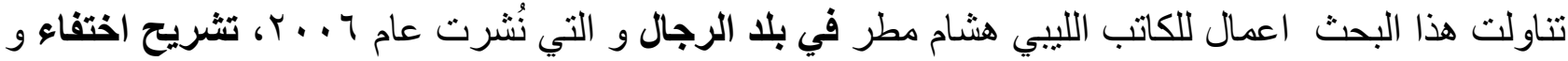

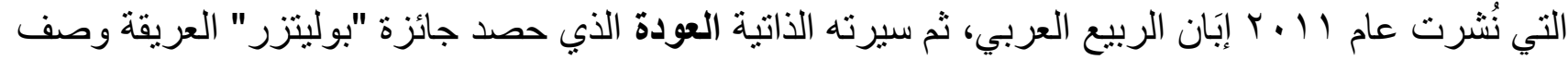

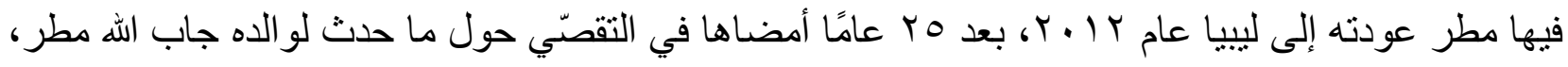
المعارض لنظام القذافي الذي كان يعيش في القاهرة حين اختطفه رجال القذافي عام • 199 و و اقتادوه إلى السجن في ليبيا حيث توارى في ظروف لا تزال غامضة. يلجأ مطر إلى المظاهر الثقافية و السياسية و الاجتماعية لليبيا لتشكيل و عي قر ائه. والتعرف على هذه البقعة التي ظلت مجهولة طو ال سنوات عجاف من حكم العقيد، ظلّ يأمل فيها اللبييّون أن يأتي عام تغاث فيه أحلامهم و طموحاتهم. لم يكتف مطر بسرد المظاهر التاريخية لليبيا فقط ولكنه

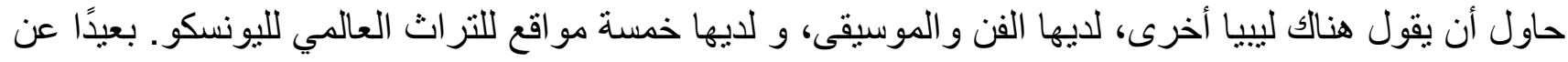
ليبيا القذافي و لم يهمل موضو عه الرئيسي و السبب ور اء كتاباته ألا و هو معرفة مصير والده. 
